\title{
PENERAPAN ALGORITMA NAÏVE BAYES PADA PENILAIAN KINERJA PEMERINTAH DESA DALAM PENGELOLAAN DANA DESA
}

\author{
Muliadi 1, Syafruddin Syarif ${ }^{2}$, Agus Salim \\ 1,2,3 Pascasarjana Sistem Komputer \\ STMIK Handayani Makassar \\ http://pps.handayani.ac.id/ \\ ${ }^{1}$ muliadiscdtolis@gmail.com
}

\begin{abstract}
ABSTRAK
Tujuan dari penelitian ini untuk mengklasifikasikan pemerintah desa mana yang baik dan buruk dalam pengelolaan dana desa di kab Tolitoli untuk menjadi acuan untuk pemerintah daerah untuk mengontrol kinerja pemerintah desa dalam mengelolaan dana desa.Metode yang digunakan dalam penelitian ini ialah naïve bayes klasifikasi berbasis pemrograman PHP dengan komputerisasi diharapkan dapat membantu penilaian kinerja pemerintah desa dalam pengelolaan dana desa agar lebih cepat dan tepat dalam mengklasifikasikan kinerja pemerintah desa.Berdasarkan hasil analisis perhitungan yang sudah dilakukan, penerapan metode naïve bayes klasifikasi dalam penilaian kinerja pemerintah desa yang sudah di lakukan terhadap 2(dua) desa dengan kreteria yang digunakan : jumlah anggaran, anggaran bidang pemerintahan, anggaran bidang pembangunan, anggaran bidang pemberdayaan, anggaran bidang pembinaan, anggaran tak terduga dan sisa anggaran sehingga hasil akhir penilaian kinerja pemerintah desa dalam pengelolaan dana desa yakni desa dengan nama desa Teluk Jaya dinyatakan baik karena memiliki nilai likelihood baik $3.57921 E^{-58}>$ nilai likelihood buruk $3.39635 E^{-60}$ sedangkan desa dengan nama desa Salumpaga dinyatakan buruk karena memiliki nilai likelihood baik $2.421 E^{-139}<$ nilai likelihood buruk $3.20355 E^{-83}$
\end{abstract}

Kata Kunci: Algoritma Naïve Bayes Klasifikasi , Penilaian Kinerja Pemerintah Desa, Pengelolaan Dana Desa

\begin{abstract}
The purpose of this study is to classify which village government is good and bad in managing village funds in Tolitoli regency to be a reference for local government to control the performance of village government in managing village funds. The method used in this research is naïve bayes classification based on PHP programming computerization is expected to help assess village government performance in village fund management so that it is faster and more accurate in classifying village government performance. Based on the analysis of calculations that have been done, the application of the naïve Bayes method of classification in village government performance appraisal has been done against 2 (two) village with criteria used: budget amount, government budget, development budget, empowerment budget, guidance field budget, unexpected budget and remaining budget so that the final result of village government performance assessment in management village funds namely villages with the name Teluk Jaya village are declared good because they have a good likelihood value of $3.57921 E^{\wedge}$ (-58)> bad likelihood value of $3.39635 E^{\wedge}$ (-60) while the village with the name Salumpaga village is declared bad because it has a good likelihood value of $2.421 E^{\wedge}(-139)$ $<$ bad likelihood value $3.20355 E^{\wedge}$ (-83)
\end{abstract}

Keywords: Nä̈ve Bayes Classification Algorithm, Village Government Performance Assessment, Village Fund Management

\section{PENDAHULUAN}

Pemerintah desa diyakini lebih mampu melihat prioritas kebutuhan masyarakat dibandingkan Pemerintah Kabupaten yang secara nyata memiliki ruang lingkup permasalahan lebih luas dan rumit (Romantis \& Ainurrohma, 2015), (Aminah \& Sari, 2018). Untuk itu, pembangunan pedesaan yang dilaksanakan harus sesuai dengan masalah yang dihadapi, potensi yang dimiliki, 
aspirasi masyarakat dan prioritas pembangunan pedesaan yang telah ditetapkan. Pemerintah kemudian mengeluarkan Peraturan Pemerintah No. 72 Tahun 2005 tentang Desa dan Peraturan Menteri Dalam Negeri Nomor 37 tahun 2007 tentang Pedoman Pengelolaan Keuangan Desa. Pemerintah daerah mempunyai kewenangan yang lebih luas dalam pengelolaan daerahnya. Salah satu bentuk kepedulian pemerintah terhadap pengembangan wilayah pedesaaan adalah adanya anggaran pembangunan secara khusus yang dicantumkan dalam Anggaran Pendapatan dan Belanja Daerah (APBD) untuk pembangunan wilayah pedesaan, yakni dalam bentuk Anggaran Dana Desa (ADD).

Dengan adanya (ADD) pemerintah desa mempunyai peranan penting dalam pengelolaan dana desa tetapi belum adanya sistem kontrol, yang baik sebagai standar untuk menentukan pemerintah desa mana kinerjanya baik dan buruk dalam mengelolah dana desa sehingga daerah tidak mengetahui kinerja pemerintah desa dalam pengelolaan dana desa, untuk itu pemerintah daerah harus mengklasifikasikan kinerja pemerintah desa mana yang kinerja nya baik dan buruk.

Pengklasifikasian tersebut dapat menggunakan beberapa algoritma misalnya Kmeans, C45, kNN dan Naïve bayes. Tapi pada kasus ini penulis menggunakan Algoritma Naïve bayes untuk mengklasifikasikan kinerja (Iskandar \& Suprapto, 2016) pemerintah dalam mengelola dana desa karena melihat keunggulan algoritma naïve bayes dengan algoritma lain contohnya mampu menangani data kuantitatif dan diskrit, cepat dan efesien ruangan, cukup akurat, kokoh terhadap attibut yang relevan dan tentunya popular [menurut Ashraf Udin , South Asian University](Wati \& Hadi, 2017). Dengan data yang sudah diklasifikasikan menggunakan naïve bayes diharapkan pemerintah daerah dapat mengontrol kinerja pemerintah desa mana yang kinerja nya baik, dan buruk.

\section{Rumusan Masalah}

a. Bagaimana membuat sistem penilaian kinerja pemerintah desa dalam pengelolaan dana desa di kab tolitoli dengan algoritma naïve bayes classifier

b. Bagaimana menentukan pemerintah desa mana yang kinerjanya baik, dan buruk dalam mengelola dana desa dengan algoritma naive bayes classifier.

\section{Tujuan Penelitian}

Berdasarkan permasalahan diatas maka tujuan penelitian yaitu :

a. Dapat mengklasifikasikan pemerintah desa mana yang kinerjanya baik, dan buruk dalam pengelolaan dana desa di kab tolitoli.

b. Dapat menjadi acuan untuk pemerintah daerah untuk mengontrol kinerja pemerintah desa dalam mengelola dana desa.

\section{METODE PENELITIAN}

\section{Desa}

Menurut Peraturan Pemerintah Nomor 72 Tahun 2005 tentang Desa, disebut bahwa Desa adalah kesatuan masyarakat hukum yang memiliki batas-batas wilayah yang berwenang untuk mengatur dan mengurus kepentingan masyarakat setempat, berdasarkan asal usul dan adat istiadat setempat yang diakui dan dihormati dalam sistem Pemerintahan Negara Kesatuan Republik Indonesia.

Sedangkan menurut Undang-Undang Nomor 6 Tahun 2014 tentang Desa, ditentukan bahwa Desa adalah desa dan desa adat atau yang disebut dengan nama lain, selanjutnya disebut Desa, adalah kesatuan masyarakat hukum yang memiliki batas wilayah yang berwenang untuk mengatur dan mengurus urusan pemerintahan, kepentingan masyarakat setempat berdasarkan prakarsa masyarakat, hak asal usul, dan/atau hak tradisional yang diakui dan dihormati dalam sistem pemerintahan Negara Kesatuan Republik Indonesia (Presiden Republik Indonesia, 2014)

\section{Alokasi Dana Desa}

Alokasi Dana Desa (ADD) adalah dana yang bersumber dari Anggaran Pendapatan dan Belanja Daerah (APBD) Kabupaten yang dialokasikan dengan tujuan pemerataan kemampuan keuangan antar Desa untuk mendanai kebutuhan Desa dalam rangka penyelenggaraan Pemerintahan dan pelaksanaan pembangunan serta pelayanan masyarakat. Alokasi Dana Desa diperoleh dari dana perimbangan APBN yang diterima oleh Kabupaten/Kota dalam Anggaran Pendapatan dan Belanja Daerah (APBD) setelah dikurangi Dana Alokasi Khusus (DAK) sebesar 10\% (Presiden Republik Indonesia, 2014)

\section{Belanja Desa}

Belanja Desa merupakan semua pengeluaran dari rekening desa yang merupakan kewajiban desa dalam 1 (satu) tahun anggaran yang tidak akandiperoleh pembayarannya kembali oleh desa. Belanja desa dipergunakan dalam rangka mendanai penyelenggaraan kewenangan desa.Belanja Desa yang ditetapkan dalam APB 
Desa sesuai pasal 100 PP Nomor 43 Tahun 2014 digunakan dengan ketentuan:

- Paling sedikit 70\% ( $\geq 70 \%$ ) dari jumlah anggaran belanja desa digunakan untuk mendanai penyelenggaraan pemerintahan desa, pelaksanaan pembangunan desa, pembinaan kemasyarakatan desa, dan pemberdayaan masyarakat desa.

- Paling banyak 30\% ( $\leq 30 \%$ ) dari jumlah anggaran belanja desa digunakan untuk:

1. Penghasilan tetap dan tunjangan kepala desa dan perangkat desa;

2. Operasional pemerintah desa;

3. Tunjangan dan operasional Badan Permusyawaratan Desa;

4. Insentif Rukun Tetangga dan Rukun Warga yaitu bantuan kelembagaan yang digunakan untuk operasional RT dan RW.

Penghasilan Tetap, operasional pemerintah desa, dan tunjangan dan operasional BPD serta insentif RT dan RW dibiayai dengan menggunakan sumber dana dari Alokasi Dana Desa. Sedangkan Penggunaan Dana Desa diprioritaskan untuk membiayai pembangunan dan pemberdayaan masyarakat. Kebutuhan pembangunan meliputi tetapi tidak terbatas pada kebutuhan primer, pelayanan dasar, lingkungan, dan kegiatan pemberdayaan masyarakat desa. Pengertian Tidak Terbatas adalah kebutuhan pembangunan di luar pelayanan dasar yang dibutuhkan masyarakat desa. Kebutuhan Primer adalah kebutuhan pangan, sandang, dan papan. Pelayanan dasar antara lain pendidikan, kesehatan, dan infrastruktur dasar.

\section{Data Mining}

Data Mining merupakan proses pengekstraksian informasi dari sekumpulan data yang sangat besar melalui penggunaan algoritma dan teknik penarikan dalam bidang statistik, pembelajaran mesin dan sistem manajemen basis data. Data mining adalah proses menganalisa data dari perspektif yang berbeda dan menyimpulkannya menjadi informasi-informasi penting yang dapat dipakai untuk meningkatkan keuntungan, memperkecil biaya pengeluaran, atau bahkan keduanya (Mustafa, Ramadhan, \& Thenata, 2017)

Definisi lain mengatakan Data Mining adalah kegiatan yang meliputi pengumpulan, pemakaian data historis untuk menemukan keteraturan, pola atau hubungan dalam data berukuran besar. Dari beberapa definisi di atas dapat ditarik kesimpulan bahwa Data Mining merupakan proses ataupun kegiatan untuk mengumpulkan data yang berukuran besar kemudian mengekstraksi data tersebut menjadi informasi - informasi yang nantinya dapat digunakan (Olson \& Delen, 2008)

\section{Data Training}

Data training digunakan untuk membentuk sebuah model classifier. Model ini merupakan representasi pengetahuan yang akan digunakan untuk prediksi kelas data baru yang belum pernah ada. Data ini akan digunakan untuk proses mining berupa 40 sampel penggunaan anggaran dana desa tahun 2015-2016 dengan pengklasifikasiaan 12 desa yang dianggap kinerja Baik dan 28 desa kinerja dianggap buruk data ini memiliki attribut Tahun ,Nama Desa, Jumlah anggaran, Bidang pemerintahan, Bidang pembangunan, Bidang pembinaan, Bidang pemberdayaan, Bidang Tak terduga , Sisa anggaran ,dan hasil kinerja. Beberapa data training dapat dilihat pada tabel 1.

\section{Data Testing}

Data testing digunakan sejauh mana algoritma naïve bayes classifier berhasil melakukan klasifikasi dengan benar karna itu data yang ada pada testing set seharusnya tidak boleh ada pada training set sehingga dapat diketahui apakah model classifier sudah berhasil dalam melakukan klasifikasi data ini akan digunakan untuk mengujian, berupa data penggunaan anggaran dana desa pada tahun 2017 ,data ini memiliki attribut Tahun ,Nama Desa, Jumlah anggaran, Bidang pemerintahan, Bidang pembangunan, Bidang pembinaan, Bidang pemberdayaan, Bidang Tak terduga dan Sisa anggaran. Beberapa data testing dapat dilihat pada tabel 2 .

\section{Metode Klasifikasi}

Klasifikasi adalah proses untuk menemukan model atau fungsi yang menjelaskan atau membedakan konsep atau kelas data, dengan tujuan untuk dapat memperkirakan kelas dari suatu objek yang labelnya tidak diketahui. Dalam mencapai tujuan tersebut, proses klasifikasi membentuk suatu model yang mampu membedakan data kedalam kelas-kelas yang berbeda berdasarkan aturan atau fungsi tertentu. Model itu sendiri bisa berupa aturan "jika-maka", berupa pohon keputusan, atau formula matematis (Mustafa et al., 2017).

\section{Naïve Bayes Clasifier}

Naive Bayes Classifier adalah sebuah metoda klasifikasi yang berdasar pada teorema Bayes. Metode pengklasifikasian ini menggunakan metode probabilitas dan statistik yang pertama kali dikemukakan oleh ilmuwan Inggris bernama 
Thomas Bayes, yaitu suatu metode untuk memprediksi peluang di masa depan berdasarkan pengalaman di masa sebelumnya, sehingga metode ini dikenal sebagaiTeorema Bayes. Ciri utama dari Naive Bayes Classifier ini adalah asumsi yang sangat kuat akan independensi dari masingmasing kondisi atau kejadian (Ridwan, Suyono, \& Sarosa, 2013). Olson dan Delen dalam bukunya, menjelaskan bahwa Naive Bayes untuk setiap kelas keputusan, menghitung probabilitas dengan syarat bahwa kelas keputusan adalah benar,. Algoritma ini berdasar pada mengasumsikan bahwa atribut obyek adalah sesuatu yang independen. Probabilitas yang terlibat dalam membat perkiraan akhir dihitung sebagai jumlah frekuensi dari "master" tabel keputusan.

Naive Bayes Classifier memiliki akurasi lebih baik dibanding dengan model classifier lainnya. Penelitian yang dilakukan oleh Xhemali, Hinde dan Stone dalam jurnalnya "Naive Bayes vs. Decision Trees vs. Neural Networks in the Classification of Training Web Pages" mengatakan bahwa "Naïve Bayes Classifier memiliki tingkat akurasi yang lebih baik dibanding model classifier lainnya" (Ridwan et al., 2013). Keuntungan penggunaan Naive Bayes Classifier adalah bahwa metode ini hanya membutuhkan jumlah data pelatihan (Training Data) yang kecil untuk menentukan estimasi paremeter yang diperlukan dalam proses pengklasifikasian (Deputi Bidang Pengawasan Penyelenggaraan Keuangan Daerah, 2015). Naive Bayes sering bekerja jauh lebih baik dalam kebanyakan situasi dunia nyata yang kompleks dari pada yang diharapkan.

Persamaan teorema bayes

$\mathrm{P}(\mathrm{H} / \mathrm{X})=\frac{\mathbf{P}(\mathbf{H} \mathbf{X}) \cdot(\mathbf{H})}{\mathbf{P}(\mathbf{X})}$

\section{Keterangan :}

Data dengan class yang belum diketahui

Hipotesis data $X$ merupakan suatu class spesifik

$(H \mid X)$ : Probabilitas hipotesis $H$ berdasar kondisi $X$ (posteriori probability)

$(H)$ : Probabilitas hipotesis $H$ (prior probability)

$(X \mid H)$ : Probabilitas $X$ berdasarkan kondisi pada hipotesis

$H(X)$ : Probabilitas

Untuk menjelaskan teorema Naive Bayes Classifier, perlu diketahui bahwa proses klasifikasi memerlukan sejumlah petunjuk untuk menentukan kelas apa yang cocok bagi sampel yang dianalisis tersebut (Setyaji \& Pujiono, 2015) .Karena itu, teorema bayes di atas disesuaikan sebagai berikut :
$C \mid F 1)=\frac{\mathrm{P}(\mathrm{C}) \mathrm{P}(\mathrm{F} 1 \ldots . \mathrm{Fn} \mid \mathrm{C})}{\mathrm{P}(\mathrm{F} 1 \ldots . \mathrm{Fn})}$

Dimana Variabel C merepresentasikan kelas, sementara variabel F1 ... Fnmerepresentasikan karakteristik petunjuk yang dibutuhkan untuk melakukan klasifikasi. Maka rumus tersebut menjelaskan bahwa peluang masuknya sampel karakteristik tertentu dalam kelas C (Posterior) adalah peluang munculnya kelas C (sebelum masuknya sampel tersebut, seringkali disebut prior), dikali dengan peluang kemunculan karakteristik - karakteristik sampel pada kelas C (disebut juga likelihood), dibagi dengan peluang kemunculan karakteristik - karakteristik sampel secara global (disebut juga evidence).

Adapun alur dari metode Naive Bayes Classifier adalah sebagai berikut:

1. Baca data training

2. Hitung Jumlah dan probabilitas, namun apabila data numerik maka:

a. Cari nilai mean dan standar deviasi dari masing - masing parameter yang merupakan data numerik.

b. Cari nilai probabilistik dengan cara menghitung jumlah data yang sesuai dari kategori yang sama dibagi dengan jumlah data pada kategori tersebut.

3. Mendapatkan nilai dalam tabel mean, standart deviasi dan probabilitas

Formula perhitungan Naive Bayes Classifier berdasarkan probabilitas ditunjukkan sebagai berikut:

$p(A \mid B) \cdot p(B)=p(B \mid A) \cdot p(A)$
$p(A i \mid B)=\frac{p(A i) \cdot p(B \mid A i)}{\sum_{j}^{C}=1 p(A j) \cdot p(B \mid A j)}$

Dengan mengubah nilai $A i$ dan $A j$ kedalam vector " $\mathrm{x}$ " maka didapatkan bentuk formula sebagai berikut :

$p(x \mid i)=\frac{p(A i) \cdot p(x)}{\sum_{j}^{c}=1 p(j) \cdot p(x)}$

Adapun perhitungan Naïve bayes Classifier untuk data kontinu menggunakan distribusi gauss sebagai berikut :

$g(x, \mu, \sigma)=\frac{1}{\sqrt{2 \pi \sigma}} e^{\frac{(x-\mu)^{2}}{2 \sigma^{2}}}$

Keterangan :

$(x \mid i)=$ Probabilitas hipotesis $\mathrm{x}$ jika diberikan

fakta atau record i (Posterior probability).

$(i \mid x)=$ Mencari nilai parameter yang memberi kemungkinan yang paling besar (Likelihood)

$(x)=$ Prior probability dari I (Prior 


\section{Probability)}

(i) = Jumlah probability tuple yang muncul $\mathrm{g}=$ Distribusi Gauss

$\mu=$ Rata-rata

$\sigma=$ Standar Deviasi

\section{Skema Naïve Bayes}

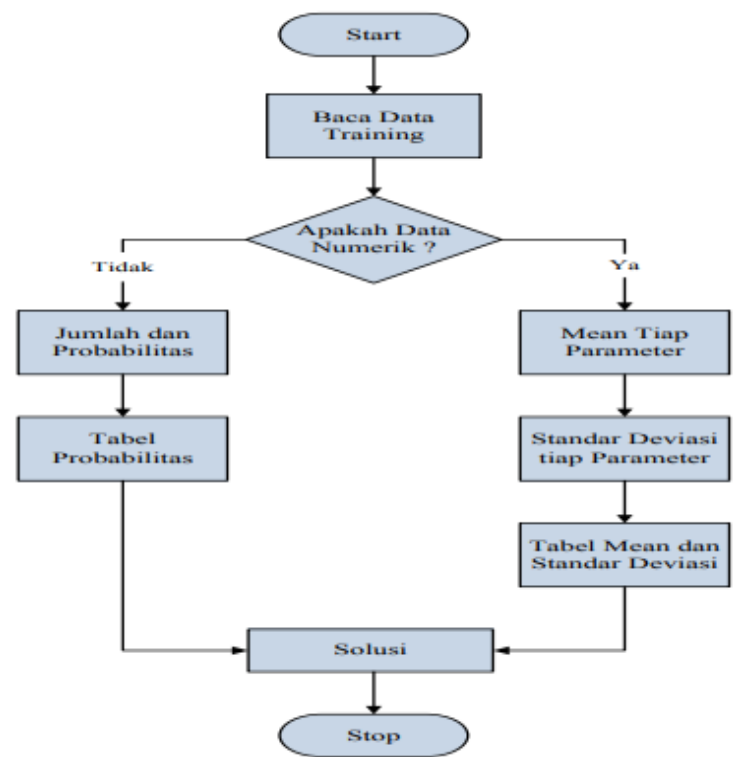

Gambar 1 Skema Naive Bayes

\section{Rancangan system}

\section{a. FlowChart}

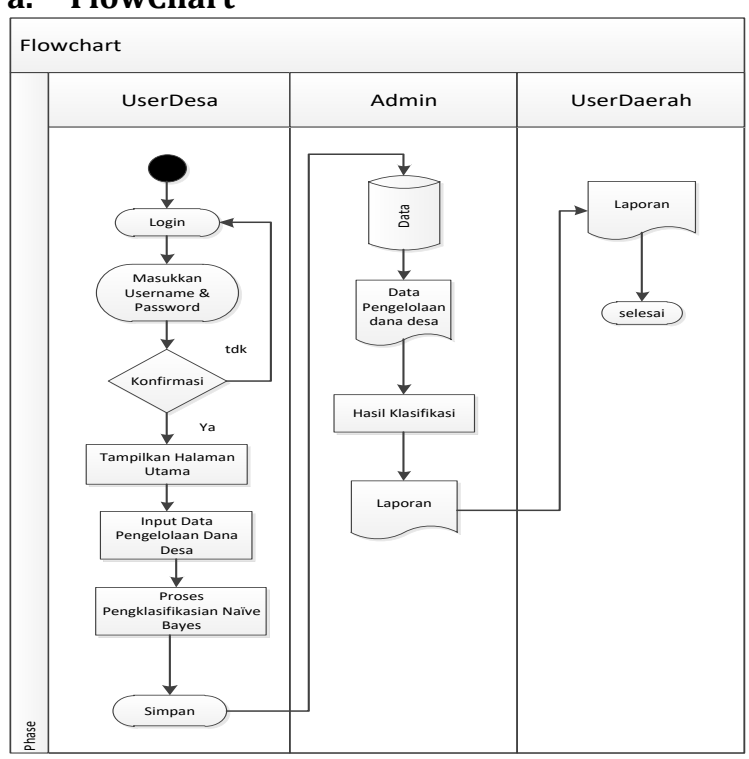

Gambar 2 FlowChart Sistem

\section{b. Use Case}
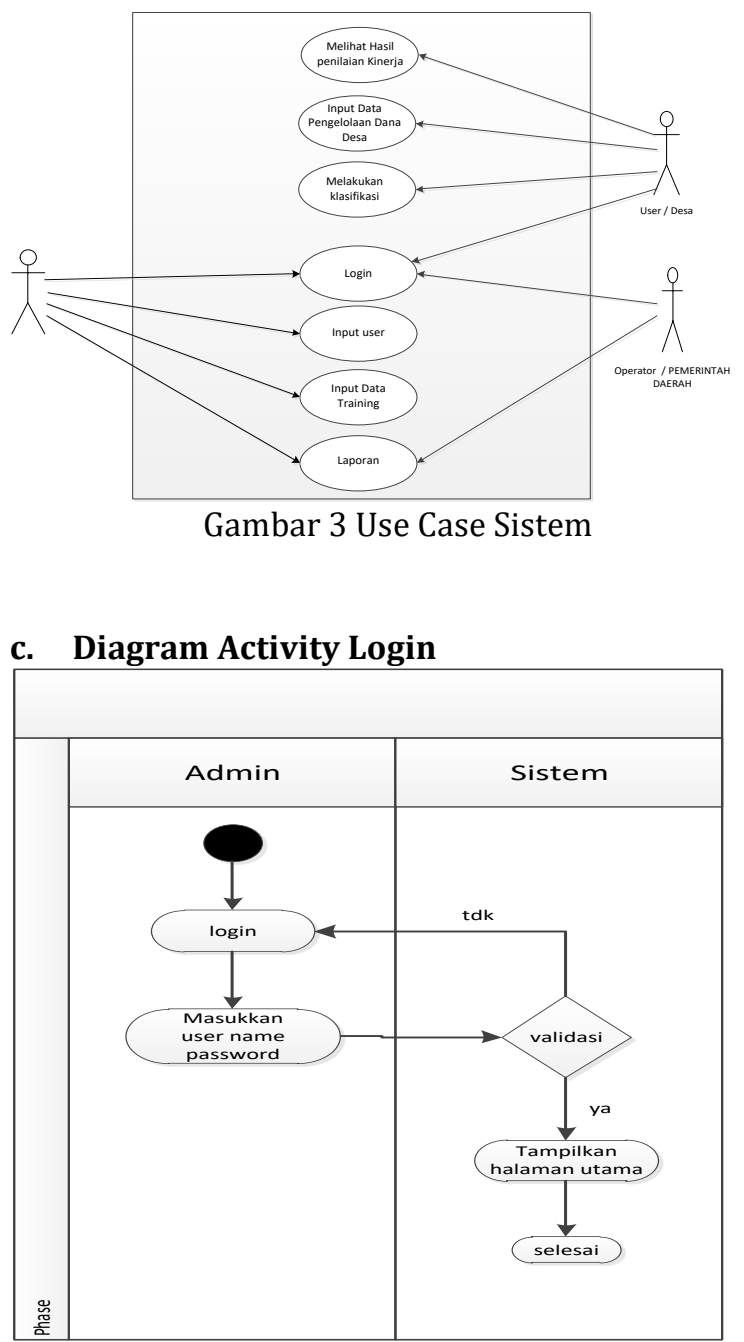

Gambar 4 Diagram Activity Login

a. Diagram Activity User

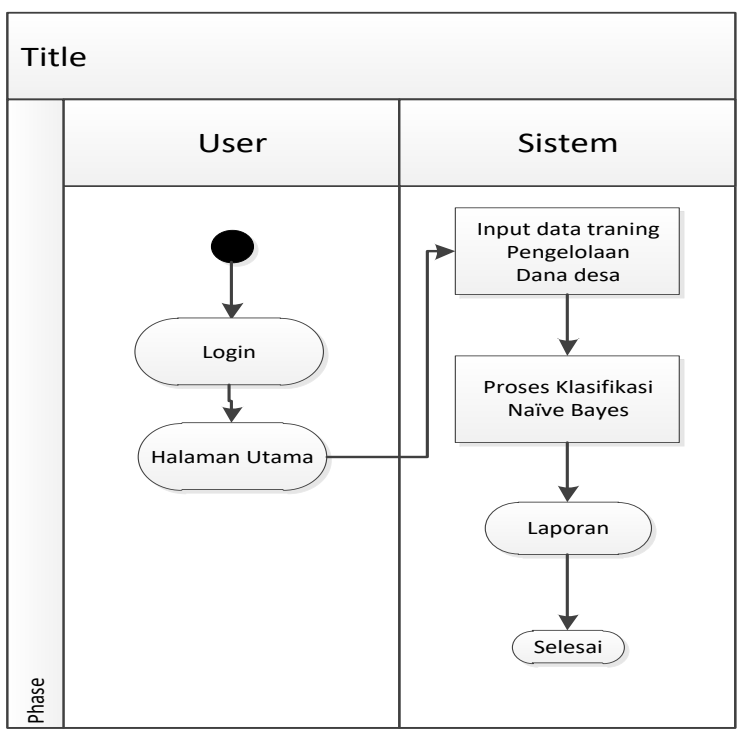

Gambar 5 Diagram Activity User 


\section{d. Penentuan Spesifikasi.}

a. Hadware

1.1. Satu unit komputer atau notbook

1.2. Memory ram minimal 1 giga

1.3. Hardisk 250 giga

b. Software

1.1. Sublime text

1.2. sql server

1.3. Php

c. Desain

1.1. Flowchart

1.2. UML

\section{HASIL PENELITIAN DAN PEMBAHASAN}

Sistem penilaian kinerja pemerintah desa dalam pengelolaan dana desa ini akan mengelompokan data desa yang sesuai dengan kreteria mana yang telah ditetap kan dalam pengelolaan dana desa, dalam kasus ini hasil klasifikasi dibagi menjadi dua(2), yaitu klasifikasi desa yang baik dan buruk.

\section{Pengolahan data}

Setelah semua data pengelolaan dana desa diinput kan maka data akan diproses dengan menggunakan algoritma Naïve bayes classifier untuk menentukan hasil klasifikasi dengan langkah sebagai berikut :

1. Inputkan jumlah dana desa dan anggaran yang telah dikeluarkan dalam setiap bidang yang telah ditentukan.

2. Dalam penelitian ini titik awal ditentukan dari data sebelum nya dapat dilihat dari tabel 1 training

Tabel 1 Data Testing

\begin{tabular}{|c|c|c|c|c|c|c|c|c|}
\hline $\begin{array}{c}\text { Tahu } \\
\text { n }\end{array}$ & $\begin{array}{c}\text { Nama } \\
\text { Desa }\end{array}$ & $\begin{array}{c}\text { Jml } \\
\text { Anggaran }\end{array}$ & $\begin{array}{c}\text { Bidang } \\
\text { pemerintah } \\
\text { an } \\
\end{array}$ & $\begin{array}{c}\text { Bidang } \\
\text { pembangun } \\
\text { an } \\
\end{array}$ & $\begin{array}{c}\text { Bidang } \\
\text { pembinaan }\end{array}$ & $\begin{array}{c}\text { Bidang } \\
\text { pemberday } \\
\text { aan } \\
\end{array}$ & $\begin{array}{c}\text { Bidang } \\
\text { tak terduga }\end{array}$ & $\begin{array}{c}\text { sisa } \\
\text { anggaran }\end{array}$ \\
\hline 2017 & $\begin{array}{l}\text { Teluk } \\
\text { Jaya }\end{array}$ & $\begin{array}{c}\text { Rp1,545,000, } \\
000\end{array}$ & $\begin{array}{c}\text { Rp440,000 } \\
000\end{array}$ & $\begin{array}{c}\text { Rp650,000,0 } \\
00\end{array}$ & $\begin{array}{c}\text { Rp152,000, } \\
000\end{array}$ & $\begin{array}{c}\text { Rp290,000,0 } \\
00\end{array}$ & $\begin{array}{c}\text { Rp6,000,00 } \\
0\end{array}$ & $\begin{array}{c}\mathrm{Rp} 7,000,00 \\
0\end{array}$ \\
\hline 2017 & $\begin{array}{c}\text { Salumpa } \\
\text { ga }\end{array}$ & $\begin{array}{c}\text { Rp2,100,000, } \\
000\end{array}$ & $\begin{array}{c}\text { Rp560,000, } \\
000\end{array}$ & $\begin{array}{c}\text { Rp900,000,0 } \\
00 \\
\end{array}$ & $\begin{array}{c}\text { Rp200,000, } \\
000\end{array}$ & $\begin{array}{c}\text { Rp250,000,0 } \\
00 \\
\end{array}$ & $\begin{array}{c}\text { Rp100,000, } \\
000\end{array}$ & $\begin{array}{c}\text { Rp90,000,0 } \\
00\end{array}$ \\
\hline
\end{tabular}

Algoritma naïve bayes classifier dalam penelitian menggunakan data testing yang diberikan dapat dilihat pada tabel 1 .

Langkah-langkah algoritma Naïve bayes classifikasi dapat dilihat pada tabel 4.2

1. Menentukan prior probality(p)

Tabel 2 Menentukan prior probality(p)

\begin{tabular}{ll}
\hline Kinerja & Jumlah \\
\hline Baik & 12 \\
\hline Buruk & 28 \\
\hline Jumlah & 40 \\
\hline
\end{tabular}

$\mathrm{P}($ Baik $)=\frac{12}{40}=0,3 \quad \mathrm{P}($ Buruk $)=\frac{28}{40}=0,7$

2. Menentukan mean dan standar deviasi untuk attribut jumlah anggaran (x1), bidang pemerintahan $(\mathrm{x} 2)$, bidang pembangunan (x3), bidang pembinaan $(\mathrm{x} 4)$, bidang pemberdayaan $(\mathrm{x} 5)$, bidang tak terduga $(\mathrm{x} 6)$, dan sisa anggaran (x7).karna nilai atrribut berupa data diskrit yang nantinya akan dimasukkan kedalam rumus distribusi gauss.

Tabel 3 Data Mean dan Stdv

\begin{tabular}{cc}
\hline & $\mathrm{x} 1$ \\
\hline Baik & Buruk \\
\hline $\mathrm{Rp} 1,708,614,700$ & $\mathrm{Rp} 2,604,839,000$ \\
\hline $\mathrm{Rp} 2,540,007,900$ & $\mathrm{Rp} 1,271,191,948$ \\
\hline $\mathrm{Rp} 1,850,005,600$ & $\mathrm{Rp} 1,606,981,900$ \\
\hline $\mathrm{Rp} 1,930,000,700$ & $\mathrm{Rp} 2,205,600,000$ \\
\hline $\mathrm{Rp} 1,606,981,900$ & $\mathrm{Rp} 1,589,000,400$ \\
\hline $\mathrm{Rp} 1,850,005,600$ & $\ldots \ldots \ldots \ldots \ldots \ldots \ldots \ldots \ldots$ \\
\hline $\mathrm{Rp} 1,405,600,000$ & $\mathrm{Rp} 2,540,007,900$ \\
\hline $\mathrm{Rp} 1,740,000,300$ & $\mathrm{Rp} 1,850,005,600$ \\
\hline $\mathrm{Rp} 1,708,614,700$ & $\mathrm{Rp} 1,405,600,000$ \\
\hline $\mathrm{Rp} 1,271,191,948$ & $\mathrm{Rp} 1,589,000,400$ \\
\hline $\mathrm{Rp} 1,708,614,700$ & $\mathrm{Rp} 1,850,005,600$ \\
\hline $\mathrm{Rp} 1,740,000,300$ & $\mathrm{Rp} 1,405,600,000$ \\
\hline $\mathrm{Rp} 21,059,638,348$ & $\mathrm{Rp} 52,543,519,456$ \\
\hline $\mathrm{Rp} 1,754,969,862$ & $\mathrm{Rp} 1,876,554,266$ \\
\hline 308939459.3 & 422878731.1 \\
\hline & \\
\hline
\end{tabular}




\begin{tabular}{cc}
\hline & $\mathrm{X} 2$ \\
\hline Baik & Buruk \\
\hline Rp498,821,900 & Rp600,039,000 \\
\hline Rp630,000,000 & Rp365,924,100 \\
\hline Rp500,006,600 & Rp320,800,000 \\
\hline Rp520,000,000 & Rp515,000,500 \\
\hline Rp430,000,000 & Rp320,400,000 \\
\hline Rp513,000,500 & $\ldots \ldots \ldots \ldots \ldots \ldots \ldots \ldots$ \\
\hline Rp390,400,000 & Rp513,000,500 \\
\hline Rp490,000,000 & Rp390,400,000 \\
\hline Rp498,821,900 & Rp310,000,000 \\
\hline Rp320,800,000 & Rp490,000,000 \\
\hline Rp430,000,000 & Rp390,400,000 \\
\hline Rp513,000,500 & Rp310,000,000 \\
\hline Rp5,734,851,400 & Rp12,486,652,300 \\
\hline Rp477,904,283 & Rp445,951,868 \\
\hline 77346301.28 & 118768388.5 \\
\hline
\end{tabular}

\begin{tabular}{|c|c|}
\hline Rp260,400,890 & Rp300,000,450 \\
\hline Rp310,000,000 & …….............. \\
\hline Rp216,000,450 & Rp300,500,000 \\
\hline Rp289,000,000 & Rp260,400,890 \\
\hline Rp210,000,000 & Rp160,451,000 \\
\hline Rp228,000,000 & Rp150,091,800 \\
\hline Rp271,507,800 & Rp310,500,000 \\
\hline Rp250,334,250 & Rp110,500,000 \\
\hline Rp3,242,429,530 & Rp7,427,274,530 \\
\hline Rp270,202,461 & Rp265,259,805 \\
\hline 40781329.67 & 83122598.17 \\
\hline
\end{tabular}

\begin{tabular}{|c|c|}
\hline \multicolumn{2}{|c|}{$\mathrm{X3}$} \\
\hline Baik & Buruk \\
\hline Rp763,698,550 & Rp1,250,000,600 \\
\hline Rp1,250,088,800 & Rp610,000,000 \\
\hline Rp800,050,000 & Rp750,056,900 \\
\hline Rp900,400,000 & $\mathrm{Rp} 1,110,000,000$ \\
\hline Rp720,056,900 & Rp790,000,000 \\
\hline Rp780,050,000 & 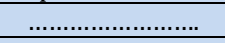 \\
\hline Rp650,000,000 & Rp763,698,550 \\
\hline Rp789,500,000 & Rp750,056,900 \\
\hline Rp763,698,550 & Rp690,000,000 \\
\hline Rp590,500,000 & Rp800,500,000 \\
\hline Rp850,400,000 & Rp750,056,900 \\
\hline Rp852,400,000 & Rp750,050,000 \\
\hline Rp9,710,842,800 & Rp22,787,936,300 \\
\hline Rp809,236,900 & Rp813,854,868 \\
\hline 163163932.8 & 203685445.8 \\
\hline \multicolumn{2}{|c|}{$\mathrm{x} 4$} \\
\hline Baik & Buruk \\
\hline Rp148,760,000 & Rp221,000,500 \\
\hline Rp300,002,320 & Rp218,230,500 \\
\hline Rp250,004,020 & Rp120,060,700 \\
\hline Rp210,000,000 & Rp230,000,000 \\
\hline Rp190,002,320 & Rp148,400,230 \\
\hline Rp230,000,000 & 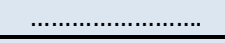 \\
\hline Rp148,400,230 & Rp170,400,000 \\
\hline Rp170,400,000 & Rp250,004,020 \\
\hline Rp230,000,000 & Rp230,000,000 \\
\hline Rp130,000,000 & Rp148,400,230 \\
\hline Rp148,400,230 & Rp270,400,000 \\
\hline Rp123,004,000 & Rp230,000,000 \\
\hline Rp2,278,973,120 & $\mathrm{Rp5}, 339,316,190$ \\
\hline Rp189,914,427 & Rp190,689,890 \\
\hline 54718576.12 & 43099385.78 \\
\hline
\end{tabular}

\begin{tabular}{|c|c|}
\hline \multicolumn{2}{|c|}{$\mathrm{x} 6$} \\
\hline Baik & Buruk \\
\hline Rp20,000,000 & \\
\hline \multicolumn{2}{|c|}{ Rp2,000,000 } \\
\hline \multicolumn{2}{|c|}{ Rp20,000,000 } \\
\hline \multicolumn{2}{|l|}{ Rp1,000,000 } \\
\hline Rp21,000,000 & Rp22,000,000 \\
\hline Rp10,500,000 & Rp11,000000 \\
\hline 13435028.84 & 9000000 \\
\hline
\end{tabular}

\begin{tabular}{|c|c|}
\hline \multicolumn{2}{|c|}{ x5 } \\
\hline Baik & Buruk \\
\hline Rp297,334,250 & Rp353,004,000 \\
\hline Rp350,400,890 & Rp71,507,800 \\
\hline Rp270,451,000 & Rp400,500,000 \\
\hline Rp289,000,000 & Rp318,000,000 \\
\hline
\end{tabular}

\begin{tabular}{|c|c|}
\hline \multicolumn{2}{|c|}{$\mathrm{x} 7$} \\
\hline Baik & Buruk \\
\hline Rp9,515,890 & Rp180,794,900 \\
\hline Rp9,493,980 & Rp5,529,548 \\
\hline Rp10,600,700 & Rp15,564,300 \\
\hline Rp6,521,790 & Rp32,599,500 \\
\hline Rp16,955,100 & $\ldots \ldots \ldots \ldots \ldots \ldots \ldots$ \\
\hline Rp799,320 & Rp792,408,850 \\
\hline Rp1,100,300 & Rp199,143,790 \\
\hline Rp6,094,250 & Rp15,149,000 \\
\hline Rp1,891,948 & Rp8,370 \\
\hline $\mathrm{Rp} 8,306,670$ & Rp128,648,700 \\
\hline Rp261,550 & Rp5,050,000 \\
\hline Rp71,541,498 & $\mathrm{Rp} 4,480,339,416$ \\
\hline Rp6,503,773 & Rp160,012,122 \\
\hline 5190571.136 & 238014836.1 \\
\hline
\end{tabular}

3. Menghitung Probabilitas dari setiap attribute.

a. Pengujian data testing pertama desa Teluk Jaya

$$
\begin{aligned}
& \mathrm{x} 1 \quad \text { : Rp1,545,000,000 } \\
& \mathrm{x} 2: \operatorname{Rp} 440,000,000 \\
& \mathrm{x} 3 \text { : } \mathrm{Rp} 650,000,000 \\
& \mathrm{x} 4: \operatorname{Rp} 152,000,000 \\
& \mathrm{x} 5 \text { : } \mathrm{Rp} 290,000,000 \\
& \text { x6 : Rp6,000,000 } \\
& \mathrm{x} 7 \quad \text { : Rp7,000,000 }
\end{aligned}
$$

\section{$\mathrm{P}(\mathrm{x1}=\mathrm{Rp1}, 545,000,000$ / Baik $)$}

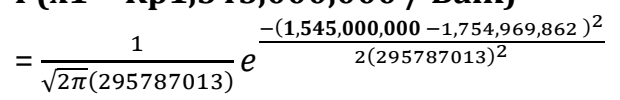


$=1.04835 \times 10^{-9}$

$P(x 1=R p 1,545,000,000$ / Buruk $)$

$=\frac{1}{\sqrt{2 \pi}(422878731.1)} e^{\frac{-(\mathbf{1}, 545,000,000-1876554266)^{2}}{2(422878731.1)^{2}}}$

$=6.9376 \times 10^{-10}$

$P(x 2=$ Rp440,000,000 / Baik $)$

$=\frac{1}{\sqrt{2 \pi}(74053445.53)} e^{\frac{-(440,000,000-477904283)^{2}}{2(74053445.53)^{2}}}$

$=\quad 4.72579 \times 10^{-9}$

$P(x 2=$ Rp440,000,000 / Buruk)

$=\frac{1}{\sqrt{2 \pi}(118768388.5)} e^{\frac{-(440,000,000-445951868)^{2}}{2(118768388.5)^{2}}}$

$=\quad 3.35478 \times 10^{-9}$

$P(x 3=$ Rp650,000,000/ Baik $)$

$=\frac{1}{\sqrt{2 \pi}(156217572.3)} e^{\frac{-(650,000,000-809236900)^{2}}{2(156217572.3)^{2}}}$

$=\quad 1.519 \times 10^{-9}$

$P(x 3=$ Rp650,000,000/ Buruk $)$

$=\frac{1}{\sqrt{2 \pi}(203685445.8)} e^{\frac{-(650,000,000-813854868)^{2}}{2(203685445.8)^{2}}}$

$=1,4500614 \times 10^{-9}$

P(X4 = Rp152,000,000/ Baik)

$=\frac{1}{\sqrt{2 \pi}(52389048.07)} e^{\frac{-(152,000,000-189914427)^{2}}{2(52389048.07)^{2}}}$

$=\quad 5.86054 \times 10^{-9}$

$P(x 4=$ Rp152,000,000/ Buruk $)$

$=\frac{1}{\sqrt{2 \pi}(43099385.78)} e^{\frac{-(152,000,000-190689890)^{2}}{2(43099385.78)^{2}}}$

$=\quad 6.18659 \times 10^{-9}$

$P(x 5=$ Rp290,000,000/ Baik $)$

$=\frac{1}{\sqrt{2 \pi}(39045150.52)} e^{\frac{-(290,000,000-270202469)^{2}}{2(39045150.52)^{2}}}$
$=8.98496 \times 10^{-9}$

$P(x 5=$ Rp290,000,000/ Buruk $)$

$=\frac{1}{\sqrt{2 \pi}(83122598.17)} e^{\frac{-(290,000,000-265259805)^{2}}{2(83122598.17)^{2}}}$
$=4.5915 \times 10^{-9}$

P(x6 = Rp6,000,000/ Baik $)$

$$
=\frac{1}{\sqrt{2 \pi}(9500000)} e^{\frac{-(6,000,000-10500000)^{2}}{2(9500000)^{2}}}
$$$$
=\quad 3.75374 \times 10^{-8}
$$

$\mathbf{P}(\mathbf{x 6}=\mathbf{R p 6 , 0 0 0 , 0 0 0 / \text { Buruk } )}$

$$
\begin{aligned}
& =\frac{1}{\sqrt{2 \pi}(9000000)} e^{\frac{-(6,000,000-11000000)^{2}}{2(9000000)^{2}}} \\
& =3.7988 \times 10^{-8}
\end{aligned}
$$

$\mathbf{P}(\mathrm{x} 7=\mathrm{Rp} 7,000,000 /$ Baik $)$

$$
\begin{aligned}
& =\frac{1}{\sqrt{2 \pi}(4949015.395)} e^{\frac{-(7,000,000-6503773)^{2}}{2(4949015.395)^{2}}} \\
& =8.02062 \times 10^{-8}
\end{aligned}
$$

$\mathbf{P}(\mathbf{x} 7=\mathrm{Rp7}, 000,000 /$ Buruk $)$

$$
\begin{aligned}
& =\frac{1}{\sqrt{2 \pi}(238014836)} e^{\frac{-(7,000,000-160012122)^{2}}{2(238014836)^{2}}} \\
& =1.36321 \times 10^{-9}
\end{aligned}
$$

Sehingga

\section{Likelihood Baik}

- $1.04835 \times 10^{-9} \times 4.72579 \times 10^{-9} \times 1.519 \times 10^{-9} \times$ $5.86054 \times 10^{-9} \times 8.98496 \times 10^{-9} \times 3.75374 \times 10^{-8}$ $\times 8.02062 \times 10^{-8} \times 0.3$

$=3.57921 \times 10^{-58}$

Likelihood Buruk

- $6.9376 \times 10^{-10} \times 3.35478 \times 10^{-9} \times 1.41718 \times 10^{-9} \mathrm{x}$ $6.18659 \times 10^{-9} \times 4.5915 \times 10^{-9} \times 3.7988 \times 10^{-8} \times$ $1.36321 \times 10^{-9} \times 0.7$

$=3.39635 \times 10^{-60}$

Kesimpulan Kinerja Pemerintah = Baik karena nilai likelihood Baik lebih besar dari likelihood Buruk.

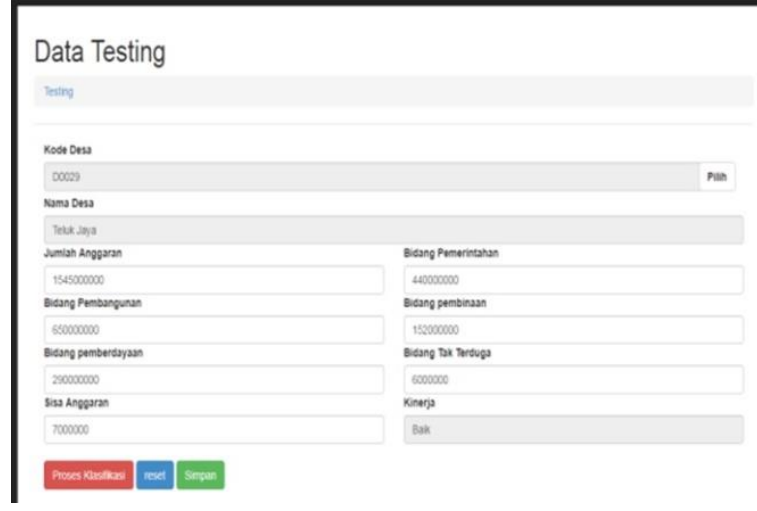

Gambar 2 Hasil Klasifikasi Baik

b. Pengujian data testing kedua desa Salumpaga

$$
\begin{aligned}
& \mathrm{x} 1 \text { : } 2,100,000,000 \\
& \mathrm{x} 2 \text { : } 560,000,000 \\
& \mathrm{x} 3 \text { : } 900,000,000 \\
& \mathrm{x} 4: 200,000,000 \\
& \mathrm{x} 5: 250,000,000 \\
& \mathrm{x} 6: 100000000 \\
& \mathrm{x} 7 \quad \text { : } 90,000,000
\end{aligned}
$$

$P(x 1=R p 2,100,000,000 /$ Baik $)$

$$
\begin{aligned}
& =\frac{1}{\sqrt{2 \pi}(295787013)} e^{\frac{-(2,100,000,000-1,754,969,862)^{2}}{2(295787013)^{2}}} \\
& =6.83067 \times 10^{-10} \\
& \mathbf{P}(x 1=\text { Rp2,100,000,000 / Buruk }) \\
& =\frac{1}{\sqrt{2 \pi}(422878731.1)} e^{\frac{-(2,100,000,000-1876554266)^{2}}{2(422878731.1)^{2}}}
\end{aligned}
$$




$$
=8.20478 \times 10^{-10}
$$

$P(x 2=$ Rp560,000,000 / Baik $)$

$$
\begin{aligned}
& =\frac{1}{\sqrt{2 \pi}(74053445.53)} e^{\frac{-(\mathbf{5 6 0}, \mathbf{0 0 0}, \mathbf{0 0 0}-477904283)^{2}}{2(74053445.53)^{2}}} \\
& =2.91401 \times 10^{-9}
\end{aligned}
$$

$\mathrm{P}(\mathrm{x} 2=\mathrm{Rp560,000,000} /$ Buruk $)$

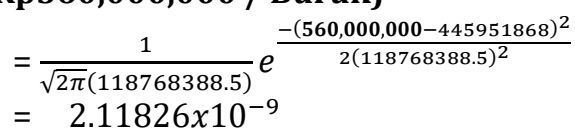

$P(x 3=R p 900,000,000 /$ Baik $)$

$=\frac{1}{\sqrt{2 \pi}(156217572.3)} e^{\frac{-(\mathbf{9 0 0}, 000,000-809236900)^{2}}{2(156217572.3)^{2}}}$
$=2.15714 \times 10^{-9}$

$P(x 3=$ Rp900,000,000/ Buruk $)$

$=\frac{1}{\sqrt{2 \pi}(203685445.8)} e^{\frac{-(\mathbf{9 0 0 , 0 0 0 , 0 0 0}-813854868)^{2}}{2(203685445.8)^{2}}}$

$=1.79105 \times 10^{-9}$

$\mathrm{P}(\mathrm{x} 4$ = Rp 200,000,000/ Baik)

$=\frac{1}{\sqrt{2 \pi}(52389048.07)} e^{\frac{-(200,000,000-189914427)^{2}}{2(52389048.07)^{2}}}$

$=7.47518 \times 10^{-9}$

$P(x 4=R p 200,000,000 /$ Buruk $)$

$=\frac{1}{\sqrt{2 \pi}(43099385.78)} e^{\frac{-(200,000,000-190689890)^{2}}{2(43099385.78)^{2}}}$

$=9.04287 \times 10^{-9}$

$P(x 5=R p 250,000,000 /$ Baik $)$

$=\frac{1}{\sqrt{2 \pi}(39045150.52)} e^{\frac{-(250,000,000-270202469)^{2}}{2(39045150.52)^{2}}}$

$=8.93736 \times 10^{-9}$

$P(x 5=R p 2500,000,000 /$ Buruk $)$

$=\frac{1}{\sqrt{2 \pi}(83122598.17)} e^{\frac{-(250,000,000-265259805)^{2}}{2(83122598.17)^{2}}}$

$=4.71925 \times 10^{-9}$

$P(x 6=R p 100,000,000 /$ Baik $)$

$=\frac{1}{\sqrt{2 \pi}(9500000)} e^{\frac{-(100,000,000-10500000)^{2}}{2(9500000)^{2}}}$

$=2.2388 \times 10^{-27}$

$P(x 6=R p 100,000,000 /$ Buruk $)$

$=\frac{1}{\sqrt{2 \pi}(9000000)} e^{\frac{-(100,000,000-11000000)^{2}}{2(9000000)^{2}}}$

$=2.58114 \times 10^{-29}$

$P(x 7=$ Rp90,000,000/ Baik $)$

$=\frac{1}{\sqrt{2 \pi}(4949015.395)} e^{\frac{-(90,000,000-6503773)^{2}}{2(4949015.395)^{2}}}$
$=1.25192 \times 10^{-69}$

$\mathrm{P}(\mathrm{x} 7=\mathrm{Rp} 90,000,000 /$ Buruk $)$

$$
\begin{aligned}
& =\frac{1}{\sqrt{2 \pi}(238014836)} e^{\frac{-(90,000,000-160012122)^{2}}{2(238014836)^{2}}} \\
& =1.33471 \times 10^{-11}
\end{aligned}
$$

Sehingga

Likelihood Baik

$\begin{array}{llcc}6.83067 \times 10^{-10} \times \mathrm{x} & 2.91401 \times 10^{-9} & \mathrm{X} \\ 2.15714 \times 10^{-9} \mathrm{x} & 7.47518 \times 10^{-9} & \mathrm{X} \\ 8.93736 \times 10^{-9} \mathrm{x} & 2.2388 \times 10^{-27} & \mathrm{X} \\ 1.25192 \times 10^{-69} \times 0.3= & 2.421 \times 10^{-139} & \end{array}$

Likelihood Buruk

- $8.20478 \times 10^{-10}$ x $2.11826 \times 10^{-9} \quad$ x $1.79105 \times 10^{-9} \quad \mathrm{X} \quad 9.04287 \times 10^{-9} \quad \mathrm{X}$ $4.71925 \times 10^{-9} \quad x \quad 2.58114 \times 10^{-29} \quad x$ $1.33471 \times 10^{-11} \times 0.7=3.20355 \times 10^{-83}$

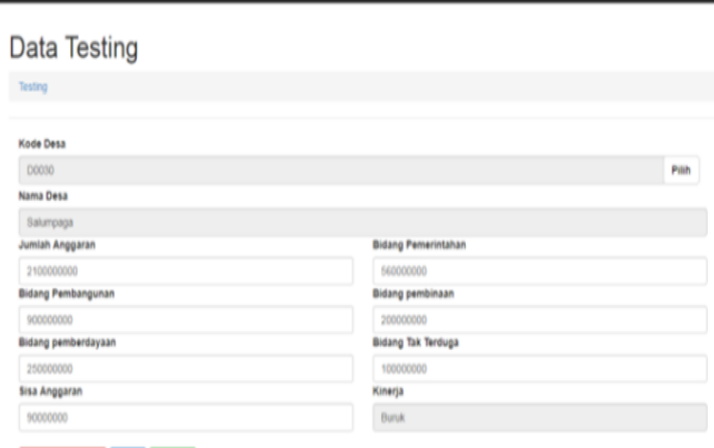

Gambar 3 Hasil Klasifikasi Buruk

KESIMPULAN DAN SARAN

\section{Kesimpulan}

Berdasarkan hasil analisis perhitungan yang sudah dilakukan, penerapan metode naïve bayes klasifikasi dalam penilaian kinerja pemerintah desa yang sudah di lakukan terhadap 2(dua) desa dengan kreteria yang digunakan adalah jumlah anggaran, anggaran bidang pemerintahan, anggaran bidang pembangunan, anggaran bidang pemberdayaan, anggaaran bidang pembinaan , anggaran tak terduga dan sisa anggaran sehingga hasil akhir penilaian kinerja pemerintah desa dalam pengelolaan dana desa yakni desa dengan nama desa Teluk Jaya dinyatakan baik karena memiliki nilai likelihood baik $3.57921 E^{-58}>$ nilai likelihood buruk $3.39635 E^{-60}$ sedangkan desa dengan nama desa Salumpaga dinyatakan buruk karena memiliki nilai likelihood baik $2.421 E^{-139}<$ nilai likelihood buruk $3.20355 E^{-83}$. 


\section{Saran}

Pengembangan penelitian selanjutnya yang perlu dilakukan sebagai berikut: Penelitian selanjutnya dapat dikembangkan dengan menggunakan data training yang lebih banyak dan kreteria-kreteria yang digunakan lebih detail. Pada penerapan algoritma naïve bayes classifier dalam penilaian kinerja pemerintah desa dapat di padukan dengan algoritma pengklasifikasian lainnya.

\section{DAFTAR PUSTAKA}

Aminah, A., \& Sari, N. (2018). PENGELOLAAN DAN PEMANFAATAN DANA DESA UNTUK PEMBERDAYAAN MASYARAKAT (Studi Kasus Di Gampong Gunong Meulinteung Kecamatan Panga Kabupaten Aceh Jaya). Jurnal Public Policy, 4(1), 22-32. Retrieved from

http://jurnal.utu.ac.id/jppolicy/article/vie $\mathrm{w} / 238$

Deputi Bidang Pengawasan Penyelenggaraan Keuangan Daerah. (2015). Petunjuk Pelaksanaan Bimbingan dan Konsultasi Pengelolaan Keuangan Desa. Jakarta.

Iskandar, D., \& Suprapto, Y. K. (2016). PERBANDINGAN AKURASI KLASIFIKASI TINGKAT KEMISKINAN ANTARA ALGORITMA C 4.5 DAN NAÏVE BAYES. Network Engineering Research Operation, 2(1). https://doi.org/10.28961/NERO.V2I1.42

Mustafa, M. S., Ramadhan, M. R., \& Thenata, A. P. (2017). Implementasi Data Mining untuk Evaluasi Kinerja Akademik Mahasiswa Menggunakan Algoritma Naive Bayes Classifier. Creative Information Technology Journal (CITEC Journal), 4(2). Retrieved from

http://citec.amikom.ac.id/main/index.php/ citec/article/view/106
Olson, D. L., \& Delen, D. (2008). Advanced data mining techniques (1st ed.). Verlag Berlin Heidelberg: Springer. https://doi.org/10.1007/978-3-54076917-0

Presiden Republik Indonesia. Undang-Undang Republik Indonesia Nomor 6 Tahun 2014 Tentang Desa, Pub. L. No. 6, 38 (2014). Indonesia. Retrieved from http://www.dpr.go.id/dokjdih/document/ uu/UU_2014_6.pdf

Ridwan, M., Suyono, H., \& Sarosa, M. (2013). Penerapan Data Mining Untuk Evaluasi Kinerja Akademik Mahasiswa Menggunakan Algoritma Naive Bayes Classifier. Jurnal EECCIS (Electrics, Electronics, Communications, Controls, Informatics, Systems)., 7(1), 59-64. Retrieved from https://jurnaleeccis.ub.ac.id/index.php/eec cis/article/view/204

Romantis, P. A., \& Ainurrohma, P. (2015). AKUNTABILITAS PENGELOLAAN ALOKASI DANA DESA DI KECAMATAN PANARUKAN KABUPATEN SITUBONDO TAHUN 2014 (No. 65226). Kabupaten Jember. Retrieved from http://repository.unej.ac.id/handle/12345 $6789 / 65226$

Setyaji, B., \& Pujiono, P. (2015). SISTEM PENDUKUNG KEPUTUSAN PENENTUAN KELAYAKAN TENAGA KERJA MENGGUNAKAN METODE NAIVE BAYES CLASSIFICATION (No. 16562). Semarang. Retrieved from http://eprints.dinus.ac.id/16562/

Wati, M., \& Hadi, A. (2017). Implementasi Algoritma Naive Bayesian Dalam Penentuan Penerima Program Bantuan Pemerintah. STMIK KHARISMA Makassar, 3(1), 22-26. 